\title{
Biology and Management of Pusley (Richardia L.) in Turfgrass and Landscape Planting Beds ${ }^{1}$
}

\author{
Evan Anderson, Pawel Petelewicz, and Chris Marble²
}

\section{Introduction}

Four species of pusley (Richardia L.) occur in Florida (Lewis and Oliver 1974): Brazil pusley (R. brasiliensis Gomes), largeflower pusley (R. grandiflora [Cham. \& Schltdl.] Schult. \& Schult. f.), South American Mexican clover (R. humistrata [Cham. \& Schltdl.] Schult. \& Schult. f.), and Florida pusley (R. scabra L.). The Florida Plant Atlas classifies all four species as being introduced, while the USDA plant database classifies R. scabra and R. brasiliensis as native (USDA-NRCS 2021; Wunderlin et al. 2021). All four species are similar in appearance, distribution, and growth habit. As weeds, Florida pusley and Brazil pusley are the most common, being found in turfgrass, pastures, and horticultural operations throughout Florida. Largeflower pusley can also become problematic in landscapes, especially in south Florida. This article was written for homeowners and green industry professionals to help aid in the identification and management of the three most common pusleys, including Florida, Brazilian, and largeflower pusley (Richardia spp.), in turfgrass and landscape planting beds.

\section{Species Description}

\section{Class}

Dicotyledonous plant

\section{Family}

Rubiaceae (coffee and madder family)

\section{Other Common Names}

Richardia scabra (Florida pusley): Mexican clover, rough Mexican clover, Florida snow weed

Richardia braziliensis (Brazil pusley): tropical Mexican clover, Brazilian pusley

Richardia grandiflora (Largeflower pusley): largeflower Mexican clover, Florida snow weed

\section{Life Span}

Florida, Brazilian, and largeflower pusleys are all warmseason annuals, but Brazilian and largeflower pusley commonly persist as perennials in warmer climates such as central and south Florida (Lewis and Oliver 1974).

\section{Habitat}

All three species are found in a wide range of environments, ranging from cultivated areas such as lawns and landscape planting beds to pastures, agricultural fields, and waste sites (Bryson and DeFelice 2009; Lewis and Oliver 1974; Sharpe et al. 2019).

1. This publication is ENH1346, one of a series of the Environmental Horticulture Department, UF/IFAS Extension. Original publication date September 2021. Visit the EDIS website at https://edis.ifas.ufl.edu for the currently supported version of this publication.

2. Evan Anderson, Extension agent I, horticulture, UF/IFAS Extension Walton County, DeFuniak Springs, FL; Pawel Petelewicz, assistant professor, Agronomy Department, Gainesville, FL; and Chris Marble, associate professor, Environmental Horticulture Department, UF/IFAS Mid-Florida Research and Education Center, Apopka, FL; UF/IFAS Extension, Gainesville, FL 32611.

The use of trade names in this publication is solely for the purpose of providing specific information. UF/IFAS does not guarantee or warranty the products named, and references to them in this publication do not signify our approval to the exclusion of other products of suitable composition.

Use pesticides safely. Read and follow directions on the manufacturer's label.

The Institute of Food and Agricultural Sciences (IFAS) is an Equal Opportunity Institution authorized to provide research, educational information and other services only to individuals and institutions that function with non-discrimination with respect to race, creed, color, religion, age, disability, sex, sexual orientation, marital status, national origin, political opinions or affiliations. For more information on obtaining other UF/IFAS Extension publications, contact your county's UF/IFAS Extension office. U.S. Department of Agriculture, UF/IFAS Extension Service, University of Florida, IFAS, Florida A \& M University Cooperative Extension Program, and Boards of County Commissioners Cooperating. Nick T. Place, dean for UF/IFAS Extension. 


\section{Distribution}

Florida and Brazilian pusley grow throughout the southeast United States, from Florida to as far west as Texas and as far north as Maryland (USDA-NRCS 2021). Largeflower pusley is found throughout Florida and in other tropical environments including Hawaii, Jamaica, Africa, and southern Asia (Lewis and Oliver 1974; USDA-NRCS 2021).

\section{Growth Habit}

All species of pusley have a similar growth habit, typically remaining low-growing along the ground (prostrate)

(Figure 1). It is rarely able to compete with well-established stands of grass or in mulched planting beds but can thrive in open areas or in severely thin swards and dead patches of turf.

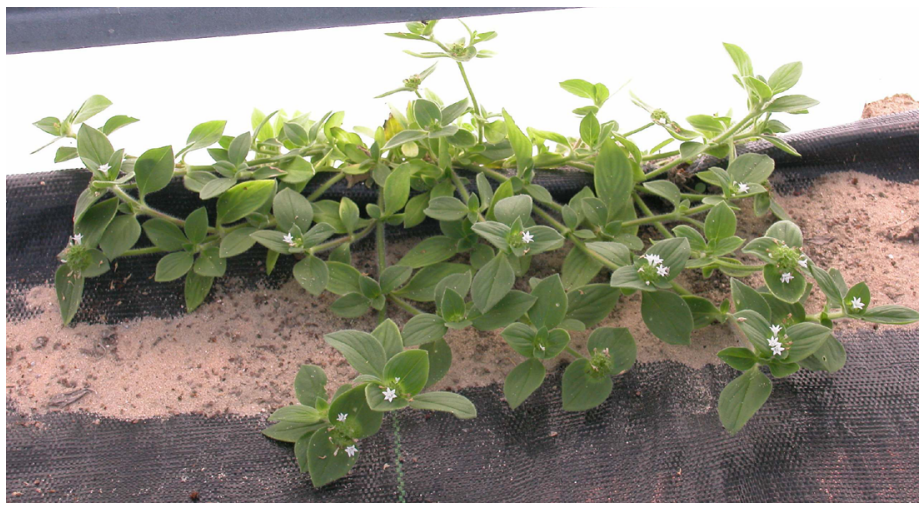

Figure 1. Brazilian pusley growing low along the ground.

Credits: Annette Chandler, UF/IFAS

\section{Seedlings}

The initial stem that arises from the seed (hypocotyls) is green and lacks hair. It may be slightly maroon to reddish in color on the upper portion of the leaf. Cotyledons (seed leaves that first emerge from the seed coat upon germination) are smooth with thick blades (Bryson and DeFelice 2009) (Figure 2).

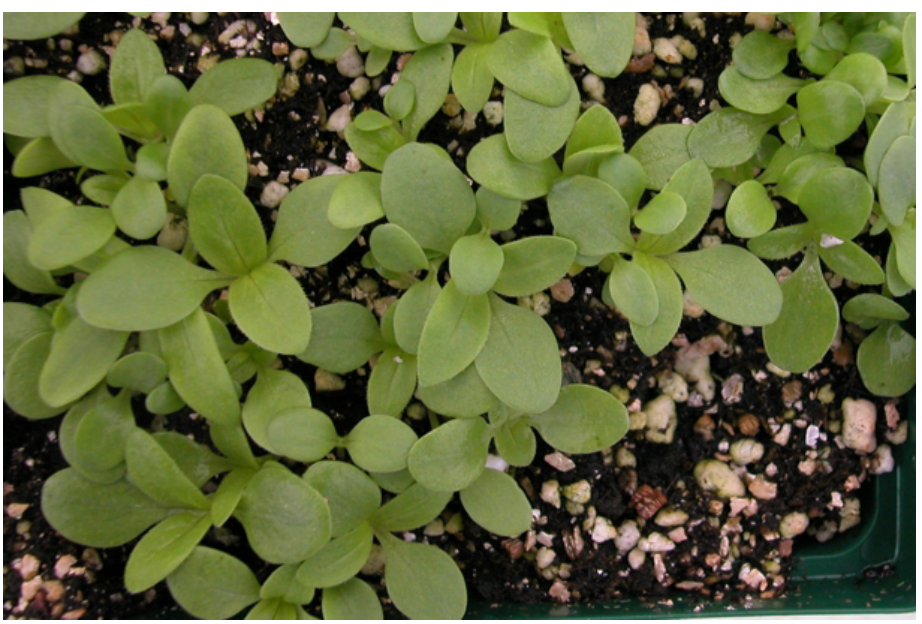

Figure 2. Florida pusley seedlings. Credits: Annette Chandler, UF/IFAS

\section{Shoots and Leaves}

Stems are round or oval and covered in many stiff hairs (pubescence). Stems can grow up to 30 inches in length, growing laterally along the ground. Leaves are opposite and covered in hairs (Figure 3). Leaf shapes may vary depending on the conditions where the plant is growing (sun, shade, etc.); therefore, leaf shape is not a good species identifier (Lewis and Oliver 1974). In general, however, Florida pusley has egg-shaped (ovate) to teardrop-lanceshaped (elliptic-lanceolate) leaves. Brazil pusley has teardrop (elliptic) to ovate leaves with the leaf tips (apex) being triangular to rounded (acute to obtuse). Largeflower pusley has very lance-shaped (linear-lanceolate) leaves, which have no leaf stalk (sessile) (Lewis and Oliver 1974).

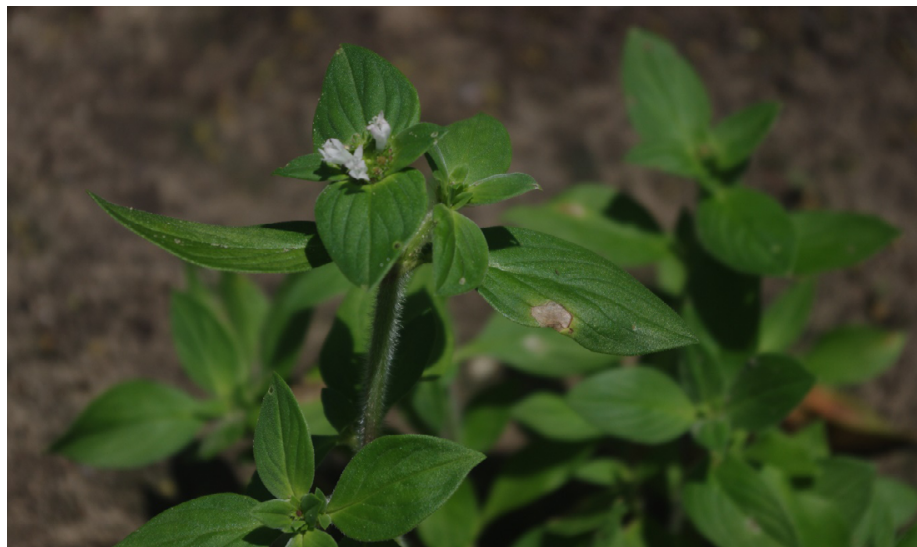

Figure 3. Pusley stems and leaves. Note the thick hairs on the stems and opposite leaf arrangement.

Credits: Annette Chandler, UF/IFAS

\section{Roots}

Pusley plants have a large, dominant root (taproot) and fibrous roots branching off the main taproot. Largeflower pusley is commonly found rooting adventitiously along the nodes on its stems, while Florida and Brazilian pusley will only rarely root along their stems.

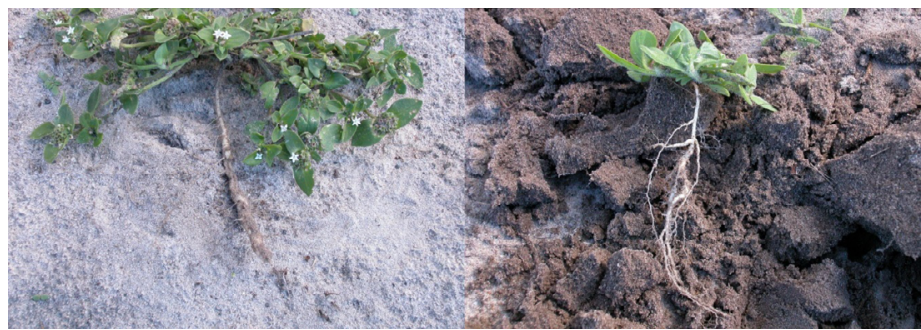

Figure 4. Brazilian pusley tap roots and fibrous roots branching off the main tap root.

Credits: Annette Chandler, UF/IFAS

\section{Inflorescence}

The flowering head structure (capitulum) contains many flowers. Floral parts such as petals are in groups of six. Flowers are funnel-shaped (funnelform) and can be found on plants year-round (Lewis and Oliver 1974). Flowers 
on Florida and Brazilian pusley are much smaller than the flowers on largeflower pusley (Figures 5 and 6). While flower petals on Florida and Brazilian pusley are white, largeflower pusley can have flowers that are pink, lavender, or lilac in color.

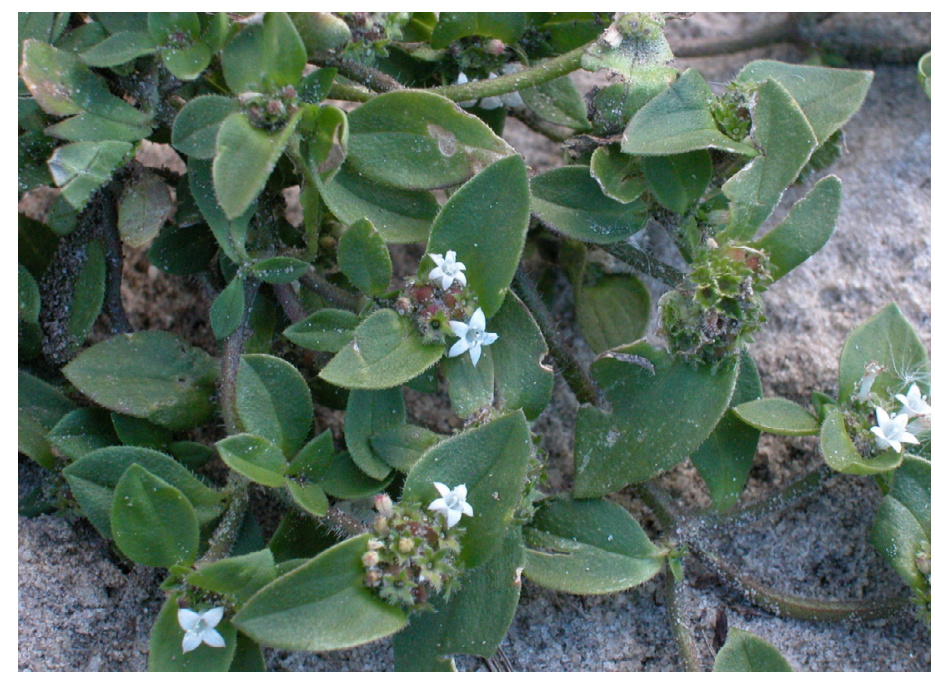

Figure 5. Florida pusley flowers. Brazilian pusley flowers look very similar in appearance.

Credits: Annette Chandler, UF/IFAS

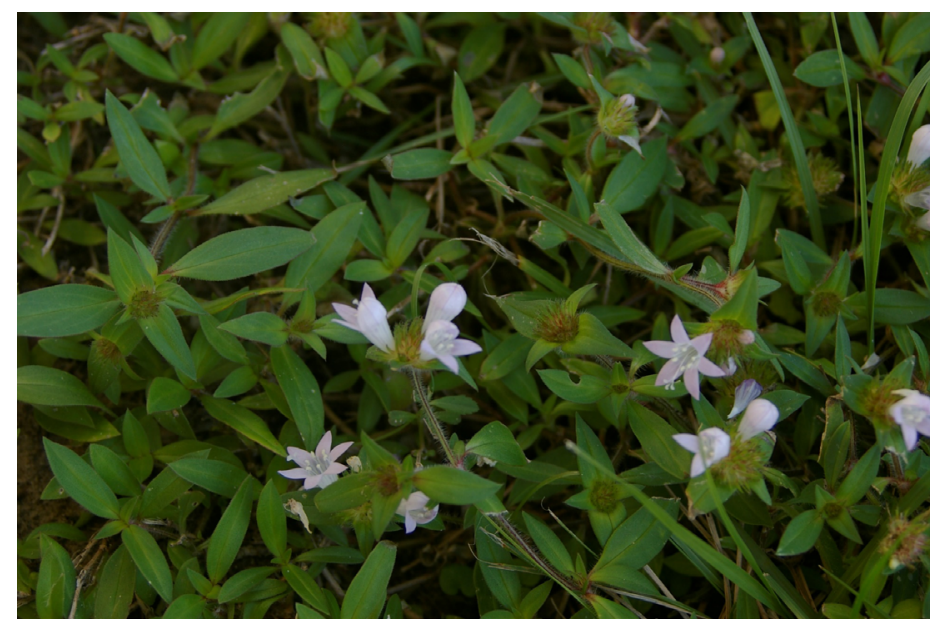

Figure 6. Largeflower pusley flowers. Flowers on large flower pusley can be much larger than flowers on Florida or Brazilian pusley and may be pink or lilac in color.

Credits: Annette Chandler, UF/IFAS

\section{Fruit and Seeds}

Pusley bears a dried fruit (schizocarp), which is divided into three sections (mericarps) (Lewis and Oliver 1974). Once mature, mericarps typically fall from the fruiting structure. Examination of mericarps is the best method of identication between Florida, Brazil, and largeflower pusley (Lewis and Oliver 1974). Florida and largeflower pusley both have wart-like outgrowths, while Brazil pusley has hair-like outgrowths. After formation, Florida pusley seeds may germinate almost immediately, needing a minimal after-ripening period to become viable (Biswas et al. 1975).

\section{Similar Species}

South American Mexican clover ( $R$. humistrata) is very similar to the other three species found in Florida, especially Florida and Brazilian pusley, but is a perennial with floricarps and mericarps in groups of four rather than six (Louis and Oliver 1974). Additionally, the mericarps on South American Mexican clover are smooth, while the other species contain either wart-like outgrowths (Florida and largeflower) or hair-like outgrowths (Brazil pusley).

\section{Plant Biology}

Both Florida and Brazilian pusley spread primarly via seed, while largeflower pusley can spread via seed or by rooting along its nodes on the stems (Figure 7). All three species can also be spread by stem fragments that can root if the conditions are ideal. Little information is available on Brazilian or largeflower pusley seed germination. However, seeds of Florida pusley germinate on the soil surface. Burial deeper than $0.5 \mathrm{~cm}$ impedes germination (Biswas et al. 1975). Germination of Florida pusley is optimal at temperatures ranging from $68^{\circ} \mathrm{F}-95^{\circ} \mathrm{F}\left(20^{\circ} \mathrm{C}-35^{\circ} \mathrm{C}\right)$, with a $97 \%$ germination rate at $86^{\circ} \mathrm{F}\left(30^{\circ} \mathrm{C}\right)$ (Biswas et al. 1975). While germination and emergence can occur year-round in Florida, warmer temperatures favor higher germination rates and faster vegetative growth.

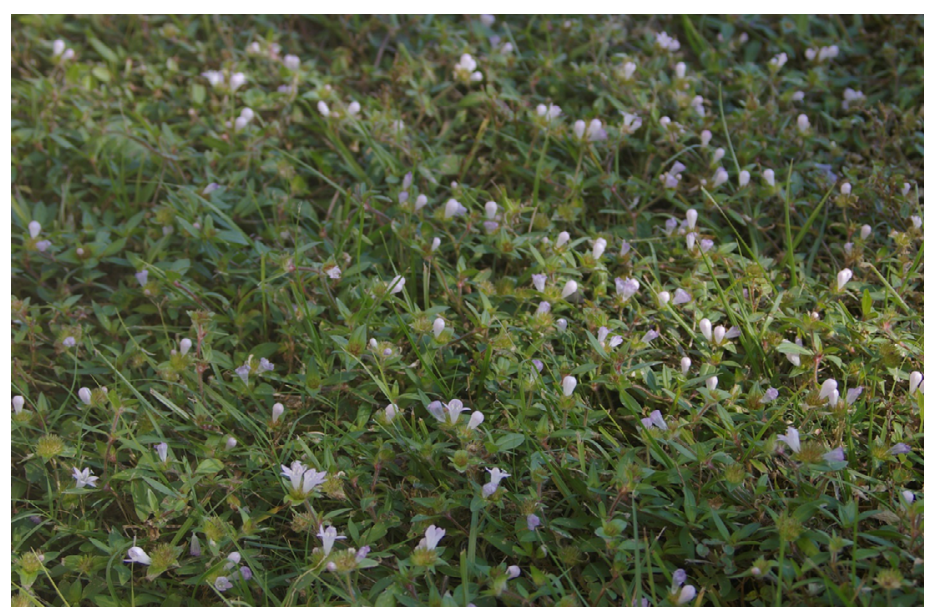

Figure 7. Largeflower pusley can root along its stems, forming dense mats in turfgrass or in landscape planting beds.

Credits: Annette Chandler, UF/IFAS

\section{Management \\ Cultural Control}

Bare spots or severely thin areas in turfgrass can quickly become colonized by pusley. Because pusley is usually not competitive with turfgrass due to its growth habit, infestations can be prevented by maintaining a healthy stand of turfgrass through proper irrigation practices, fertilization, mowing, and systematic monitoring for pests and diseases. 
In planting beds, application of mulch such as pine bark nuggets, pine straw, or wood chips to a depth of 2 to 3 inches can prevent or reduce germination of pusley species.

\section{Chemical Control}

\section{PREEMERGENCE}

There is little to no data on preemergence control of Brazilian pusley or largeflower pusley. However, many herbicides have been evaluated for control of Florida pusley. Preemergent herbicides including prodiamine (Barricade), pendimethalin (Pendulum), S-metolachlor (Pennant Magnum ${ }^{\circ}$ ), oryzalin (Surflan ${ }^{\circ}$ ), indaziflam (Specticle), isoxaben (Gallery'), and dimethenamid-P (Tower ${ }^{\circ}$ ) are all typically effective for controlling Florida pusley preemergence and can be applied in most warm-season turfgrass species to control pusley. Homeowners can typically purchase herbicides that include prodiamine, pendimethalin, or oryzalin as the active ingredient at big-box stores in small quantities, while the other herbicides listed are typically only available in large, professional-sized packages that are not cost effective for homeowner use. It is important to read and follow all label directions because not all herbicides can be used on all types of turfgrass or in particular settings.

These same preemergence herbicides can also be applied to control pusley in landscape planting beds. Additionally, herbicides such as flumioxazin (SureGuard and Broadstar ${ }^{\circ}$ ) can also be used in planting beds. Most of the above herbicides are available in either granular or spray-applied formulations. Many of these preemergence herbicides, especially when used as a granular formulation, can be applied over the top of certain ornamentals that are specifically listed on the label. Applicators should check individual product labels for specific species lists.

Timing is important for the use of any preemergent product, because they must be applied prior to seed germination. For pusley, this is typically in the spring when temperatures reach $65^{\circ} \mathrm{F}-70^{\circ} \mathrm{F}\left(18^{\circ} \mathrm{C}-21^{\circ} \mathrm{C}\right)$ for four to five days in a row. Watering preemergence herbicides into the soil (either by irrigation or rainfall) is crucial for successful control in turf. No preemergence herbicide will provide season-long control; therefore, additional applications would be needed to control pusley throughout the year.

\section{POSTEMERGENCE TREATMENT}

Treatment is most effective when the target weed plants are young. Large pusley plants that are allowed to mature have deeper roots and may require more herbicide applications for adequate control.
In general, most broadleaf herbicides can provide control of pusley, especially Florida and Brazilian pusley, which are usually easier to control than largeflower pusley. In bahia, bermuda, and zoysia lawns, products containing 2,4-D (or mixtures, such as 2,4-D and dicamba) can typically be used. These products are sold under many different trade names and are widely available at big-box retail stores. In St. Augustine lawns, options are more limited. Professionalgrade herbicides such as thiencarbazone-methyl + iodosulfuron + dicamba (Celsius WG) are labelled for Florida pusley control and can be applied to St. Augustinegrass as well as bermudagrass, centipedegrass, and zoysiagrass. Additionally, products with the active ingredient metsulfuron can be used in bermuda and zoysia in addition to St. Augustinegrass lawns. Several other herbicides are available that contain several different active ingredients, such as 2,4-D, dicamba, penoxsulam, and sulfentrazone (Avenue ${ }^{\mathrm{rm}}$ South), and are labeled for Florida pusley control in most warm-season turfgrasses. Other control options are listed in Table 1.

While homeowners may be able to purchase these professional-grade herbicides at pesticide distributors or through online sources, it is very important to use these products and all pesticides with caution. Many of these herbicides, such as metsulfuron, are applied at very low doses and can cause severe damage or death to the turf or surrounding landscape plants if the applicator does not know how to properly mix and calibrate their application equipment. If the user is unsure of how to properly calibrate their sprayer or rotary spreader, they should contact a professional pest management service.

It is also important to note that many of the herbicides used to control pusley or any weed during high heat in the summer may affect turfgrasses as well. St. Augustinegrass is prone to this sort of damage, and some herbicides such as 2,4-D or atrazine may affect grasses more when temperatures rise above $85^{\circ} \mathrm{F}-90^{\circ} \mathrm{F}\left(29^{\circ} \mathrm{C}-32^{\circ} \mathrm{C}\right)$. Turfgrass response to herbicide treatment may also differ between various cultivars of the same species or due to various other plant-related (e.g., plants maturity, rooting strength) or environmental (e.g., shade exposure, irrigation) factors. The risk that potentially safe product may cause damage to the desired stand should be considered, especially when growing conditions or turf health is not optimal.

In landscape planting beds, pusley can be controlled with directed applications of herbicides such as glyphosate (RoundUp and many other trade names), diquat (Reward), pelargonic acid (Scythe), glufosinate (Finale) and many other contact herbides labeled for use in landscape planting 
beds, such as organic acetic-acid-based herbicides or herbicides derived from plant oils. Contact herbicides, such as diquat, pelargonic acid, or organic herbicides derived from plant oils, are typically less effective than systemic herbicides, such as glyphosate, especially on large pusley plants that have begun to flower.

For further information on pre- and postemergence herbicides and other control practices for weeds in turfgrass, consult the Weed Management Guide for Florida Lawns (https://edis.ifas.ufl.edu/ep141). A more complete list of herbicide options and nonchemical control strategies is available in Improving Weed Control in Landscape Planting Beds (https://edis.ifas.ufl.edu/ep523), the Florida Homeowner Herbicide Guide (https://edis.ifas.ufl.edu/ep575), and Postemergence Herbicides for Use in Ornamentals (https:// edis.ifas.ufl.edu/wg059).

\section{References}

Biswas, P., P. Bell, J. Crayton, and K. Paul. 1975. "Germination Behavior of Florida Pusley Seeds: Effects of Storage, Light, Temperature and Planting Depths on Germination." Weed Sci 23 (5): 400-403. https://doi.org/10.1017/ S0043174500062755

Bryson, C., and M. DeFelice. 2009. Weeds of the South. Athens: University of Georgia Press.

Lewis, W. H., and R. L. Oliver. 1974. "Revision of Richardia (Rubiaceae).” Brittonia 26:271-301. https://doi. org/10.2307/2805730

Sharpe, S. M., N. S. Boyd, C. Marble, and S. Steed. 2019. "Biology and Management of Pusley (Richardia L.) in Tomato, Pepper, Cucurbit, and Strawberry Production.” EDIS 2019 (3). https://doi.org/10.32473/edis-hs1331-2019

United States Department of Agriculture-National Resources Conservation Service (USDA-NRCS). 2021. The PLANTS Database. National Plant Data Team, Greensboro, N.C., 27401-4901. http://plants.usda.gov

Wunderlin, R. P., B. F. Hansen, A. R. Franck, and F. B. Essig. 2021. Atlas of Florida Plants. https://florida.plantatlas.usf. edu 
Table 1. Herbicide options for the control or suppression of Florida pusley (Richardia scabra L.) in most prevalent Florida turfgrasses.

\begin{tabular}{|c|c|c|c|c|c|c|c|c|}
\hline \multirow{2}{*}{$\begin{array}{c}\text { HRAC/WSSA } \\
\text { Group }\end{array}$} & \multirow[t]{2}{*}{ Active Ingredient(s) } & \multicolumn{7}{|c|}{ Turfgrass Species } \\
\hline & & BER & STA & CENT & BAHI & PASP & zOYS & RYE \\
\hline \multicolumn{9}{|c|}{ PREemergence } \\
\hline \multicolumn{9}{|l|}{ Standalones } \\
\hline 5 & Atrazine & $\mathrm{R}$ & $\mathrm{T}$ & $\mathrm{T}$ & NR & NR & $\mathrm{T}$ & $\mathrm{D}$ \\
\hline 3 & DCPA & $\mathrm{T}$ & $\mathrm{T}$ & $\mathrm{T}$ & $\mathrm{T}$ & $\mathrm{T}$ & $\mathrm{T}$ & $\mathrm{T}$ \\
\hline 15 & Dimethenamid-P & $\mathrm{T}$ & $\mathrm{T}$ & $\mathrm{T}$ & $\mathrm{R}$ & $\mathrm{T}$ & $\mathrm{T}$ & $\mathrm{R}$ \\
\hline 14 & Flumioxazin & $\mathrm{R}$ & NR & NR & NR & NR & NR & $\mathrm{D}$ \\
\hline 29 & Indaziflam & $\mathrm{R}$ & $\mathrm{R}$ & $\mathrm{R}$ & $\mathrm{T}$ & D & $\mathrm{T}$ & $\mathrm{D}$ \\
\hline 21 & Isoxaben & $\mathrm{T}$ & $\mathrm{T}$ & $\mathrm{T}$ & $\mathrm{T}$ & $\mathrm{R}$ & $\mathrm{T}$ & $\mathrm{T}$ \\
\hline 3 & Oryzalin & $\mathrm{T}$ & $\mathrm{T}$ & $\mathrm{T}$ & $\mathrm{T}$ & NR & $\mathrm{T}$ & $\mathrm{D}$ \\
\hline 3 & Pendimethalin & T & T & $\mathrm{T}$ & $\mathrm{T}$ & $\mathrm{T}$ & $\mathrm{T}$ & $\mathrm{T}$ \\
\hline 3 & Prodiamine & $\mathrm{T}$ & $\mathrm{T}$ & $\mathrm{T}$ & $\mathrm{T}$ & $\mathrm{T}$ & $\mathrm{T}$ & $\mathrm{T}$ \\
\hline 5 & Simazine & $\mathrm{R}$ & $\mathrm{T}$ & $\mathrm{T}$ & NR & NR & $\mathrm{T}$ & NR \\
\hline 15 & S-metolachlor & T & $\mathrm{T}$ & $\mathrm{T}$ & $\mathrm{T}$ & NR & $\mathrm{T}$ & NR \\
\hline
\end{tabular}

\section{Two-way Premixes}

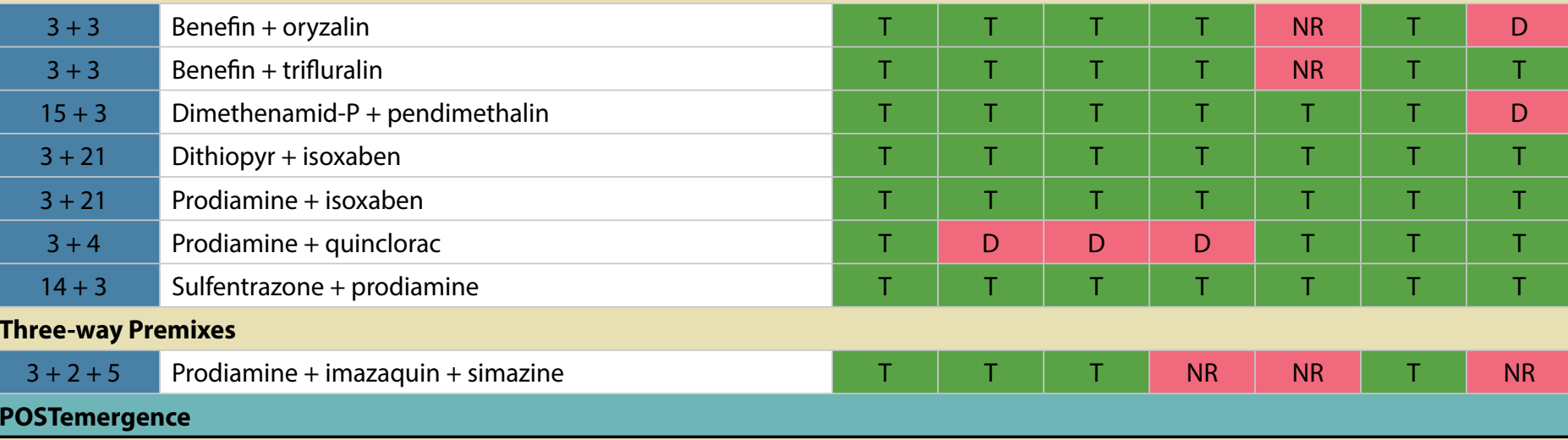

\begin{tabular}{c|l|c|c|c|c|c|c|c|c|}
\hline Standalones & & R & D & D & NR & NR & R & T \\
\hline 4 & 2,4-D & T & T & T & T & T & T & T \\
\hline 14 & Carfentrazone & T & NR & T & D & NR & NR & R \\
\hline 2 & Imazapic & D & R & T & NR & D & D & R \\
\hline 27 & Mesotrione & R & R & R & D & NR & R & NR \\
\hline 2 & Metsulfuron & R & T & T & NR & NR & T & NR \\
\hline 5 & Simazine & T & R & T & R & T & R & T \\
\hline 14 & Sulfentrazone & & & & & & \\
\hline
\end{tabular}

\section{Two-way Premixes}

\begin{tabular}{|c|l|c|c|c|c|c|c|c|c|}
\hline $4+2$ & Dicamba + metsulfuron & $\mathrm{R}$ & $\mathrm{R}$ & $\mathrm{R}$ & $\mathrm{D}$ & $\mathrm{NR}$ & $\mathrm{R}$ & $\mathrm{NR}$ \\
\hline $14+14$ & Sulfentrazone + carfentrazone & $\mathrm{T}$ & $\mathrm{R}$ & $\mathrm{T}$ & $\mathrm{R}$ & $\mathrm{T}$ & $\mathrm{R}$ & $\mathrm{T}$ \\
\hline $14+2$ & Sulfentrazone + imazethapyr & $\mathrm{T}$ & $\mathrm{NR}$ & $\mathrm{T}$ & $\mathrm{R}$ & $\mathrm{NR}$ & $\mathrm{R}$ & $\mathrm{NR}$ \\
\hline $14+2$ & Sulfentrazone + metsulfuron & $\mathrm{T}$ & $\mathrm{T}$ & $\mathrm{T}$ & $\mathrm{NR}$ & $\mathrm{NR}$ & $\mathrm{R}$ & $\mathrm{NR}$ \\
\hline $14+3$ & Sulfentrazone + prodiamine & $\mathrm{T}$ & $\mathrm{T}$ & $\mathrm{T}$ & $\mathrm{T}$ & $\mathrm{T}$ & $\mathrm{T}$ & $\mathrm{T}$ \\
\hline $14+4$ & Sulfentrazone + quinclorac & $\mathrm{T}$ & $\mathrm{NR}$ & $\mathrm{T}$ & $\mathrm{NR}$ & $\mathrm{T}$ & $\mathrm{T}$ & $\mathrm{T}$ \\
\hline
\end{tabular}

\section{Three-way Premixes}

\begin{tabular}{|c|l|c|c|c|c|c|c|c|c|}
\hline $4+4+4$ & 2,4-D + clopyralid + dicamba & $\mathrm{T}$ & $\mathrm{NR}$ & $\mathrm{NR}$ & $\mathrm{T}$ & $\mathrm{NR}$ & $\mathrm{T}$ & $\mathrm{T}$ \\
\hline $4+4+4$ & 2,4-D + fluroxypyr + dicamba & $\mathrm{T}$ & $\mathrm{D}$ & $\mathrm{D}$ & $\mathrm{T}$ & $\mathrm{NR}$ & $\mathrm{T}$ & $\mathrm{T}$ \\
\hline $4+4+4$ & 2,4-D + fluroxypyr + halauxifen-methyl & $\mathrm{T}$ & $\mathrm{D}$ & $\mathrm{D}$ & $\mathrm{NR}$ & $\mathrm{NR}$ & $\mathrm{T}$ & $\mathrm{T}$ \\
\hline $4+4+4$ & 2,4-D + MCPP + dicamba & $\mathrm{R}$ & $\mathrm{D}$ & $\mathrm{NR}$ & $\mathrm{R}$ & $\mathrm{NR}$ & $\mathrm{R}$ & $\mathrm{T}$ \\
\hline
\end{tabular}




\begin{tabular}{|c|c|c|c|c|c|c|c|c|}
\hline \multirow{2}{*}{$\begin{array}{l}\text { HRAC/WSSA } \\
\text { Group }\end{array}$} & \multirow[t]{2}{*}{ Active Ingredient(s) } & \multicolumn{7}{|c|}{ Turfgrass Species } \\
\hline & & BER & STA & CENT & BAHI & PASP & ZOYS & RYE \\
\hline $4+4+4$ & $2,4-D+$ quinclorac + dicamba & $\mathrm{R}$ & $\mathrm{D}$ & $\mathrm{D}$ & D & $\mathrm{D}$ & $\mathrm{R}$ & $\mathrm{T}$ \\
\hline $1+4+4$ & Fenoxaprop + fluroxypyr + dicamba & $\mathrm{D}$ & $D$ & D & $\mathrm{D}$ & NR & $\mathrm{T}$ & $\mathrm{T}$ \\
\hline $4+4+4$ & MCPA + fluroxypyr + dicamba & $\mathrm{T}$ & $\mathrm{T}$ & $\mathrm{T}$ & $\mathrm{T}$ & NR & $\mathrm{T}$ & $\mathrm{T}$ \\
\hline $4+4+4$ & MCPA + fluroxypyr + dichlorprop & $\mathrm{T}$ & $\mathrm{D}$ & $\mathrm{D}$ & $\mathrm{T}$ & NR & $\mathrm{T}$ & $\mathrm{T}$ \\
\hline $4+4+4$ & MCPA + fluroxypyr + triclopyr & $\mathrm{T}$ & NR & $\mathrm{T}$ & $\mathrm{T}$ & NR & $\mathrm{T}$ & $\mathrm{T}$ \\
\hline $4+4+4$ & $\mathrm{MCPA}+\mathrm{MCPP}+$ dicamba & $\mathrm{R}$ & $\mathrm{R}$ & $\mathrm{R}$ & $\mathrm{T}$ & NR & $\mathrm{R}$ & $T$ \\
\hline $4+4+4$ & MCPA + triclopyr + dicamba & $\mathrm{R}$ & $\mathrm{R}$ & $\mathrm{R}$ & $\mathrm{R}$ & NR & $\mathrm{R}$ & $\mathrm{T}$ \\
\hline $2+2+2$ & Thiencarbazone + foramsulfuron + halosulfuron & $\mathrm{T}$ & D & $\mathrm{D}$ & D & D & $\mathrm{T}$ & D \\
\hline $2+2+4$ & Thiencarbazone + iodosulfuron + dicamba & $\mathrm{T}$ & $\mathrm{T}$ & $\mathrm{T}$ & $\mathrm{D}$ & D & $\mathrm{T}$ & D \\
\hline $2+2+2$ & Thiencarbazone + iodosulfuron + halosulfuron & $\mathrm{T}$ & $\mathrm{T}$ & $\mathrm{T}$ & $\mathrm{D}$ & $\mathrm{D}$ & $\mathrm{T}$ & D \\
\hline \multicolumn{9}{|c|}{ Four-way Premixes } \\
\hline $4+4+2+14$ & 2,4-D + dicamba + penoxsulam + sulfentrazone & $\mathrm{T}$ & $\mathrm{T}$ & $\mathrm{T}$ & NR & $\mathrm{T}$ & $\mathrm{T}$ & $\mathrm{T}$ \\
\hline $4+4+4+14$ & 2,4-D + MCPA + dicamba + sulfentrazone & $\mathrm{T}$ & D & $\mathrm{T}$ & $\mathrm{T}$ & NR & $\mathrm{T}$ & $\mathrm{T}$ \\
\hline $4+4+4+14$ & 2,4-D + MCPP + dicamba + carfentrazone & $\mathrm{T}$ & $\mathrm{R}$ & $\mathrm{R}$ & $\mathrm{R}$ & $\mathrm{R}$ & $\mathrm{T}$ & $\mathrm{T}$ \\
\hline $4+4+4+14$ & 2,4-D + MCPP + dicamba + pyraflufen-ethyl & $\mathrm{T}$ & NR & NR & $\mathrm{T}$ & NR & $\mathrm{T}$ & $\mathrm{T}$ \\
\hline $4+4+4+14$ & 2,4-D + MCPP + dicamba + sulfentrazone & $\mathrm{T}$ & $\mathrm{D}$ & $\mathrm{R}$ & $\mathrm{T}$ & NR & $\mathrm{T}$ & $\mathrm{T}$ \\
\hline $4+4+4+14$ & MCPA + MCPP + dicamba + carfentrazone & $\mathrm{T}$ & $\mathrm{R}$ & NR & NR & NR & $\mathrm{T}$ & $\mathrm{T}$ \\
\hline $4+14+4+4$ & Quinclorac + sulfentrazone $+2,4-D+$ dicamba & $\mathrm{R}$ & D & $\mathrm{D}$ & D & NR & $\mathrm{R}$ & $\mathrm{T}$ \\
\hline $4+14+4+4$ & Triclopyr + sulfentrazone +2,4-D + dicamba & $\mathrm{R}$ & D & NR & $\mathrm{R}$ & NR & $\mathrm{R}$ & $\mathrm{T}$ \\
\hline \multicolumn{9}{|c|}{$\begin{array}{l}\text { T=tolerant at labeled rates on well-established (mature, dense turf having a well-anchored root system and healthy, vigorous top growth), healthy turf; R=some } \\
\text { injury may occur, and/or may cause some minor damage to mature, healthy turf, specific restrictions may apply, and/or crop safety may differ between certain } \\
\text { products; } D=\text { potentially damaging-do not use; NR=not registered for use on this species or no information provided on the label-do not use. }\end{array}$} \\
\hline \multicolumn{9}{|c|}{ Always refer to the label for specific uses, application rates, and turfgrass tolerance. Always check for specific precautions and restrictions! } \\
\hline \multicolumn{9}{|c|}{$\begin{array}{l}\text { Refer to the publication Pest Control Guide for Turfgrass Managers at http://turf.ufl.edu/pdf/2012_UF_Pest_Control_Guide.pdf for brand names associated with } \\
\text { chemical names listed. }\end{array}$} \\
\hline
\end{tabular}

